\title{
Junior College Library Section
}

\section{Meetings}

Lois E. Engleman is librarian of Frances Shimer Junior College, Mount Carroll, Illinois. Below she shows how junior college librarians participated in the twentyfirst annual meeting of the American Association of Junior Colleges, held at the Stevens Hotel in Chicago, through sectional meetings Friday afternoon, February 28, and Saturday morning, March $I$, I941.

$\mathrm{B}^{\mathrm{y}}$ APPoInTMENT of Gladys Johnson, chairman of the Junior College $\mathrm{Li}$ braries Division of the Association of College and Reference Librarians, Lois E. Engleman, librarian of Frances Shimer Junior College, served as chairman, and Maysel O'H. Baker, librarian of La SallePeru Junior College, as secretary.

In conformity to the general plan of the conference, the Friday session was devoted to a consideration of the implications of terminal education for junior college libraries. The first part of the program was a symposium on "Achievements and Plans for Library Cooperation in the Terminal Education Program of the Junior College."

Dean C. C. Flint of Santa Ana Junior College read the paper forwarded by Winifred E. Skinner, librarian, Pasadena Junior College. She reported that in accordance with the underlying philosophy of Pasadena Junior College, no particular program for terminal courses as such, has been developed. "Department chairmen are responsible, under the curriculum coordinator, for the planning of courses, terminal and academic alike, in their respective fields." Allocation of library funds is determined by a committee which considers the "needs of various departments, numbers of new courses, enrolment, and, sometimes, the timeliness of the subjects, and even the probable book production." The responsibility for ordering books for courses, then, rests with the departments which offer the courses, the librarian assisting in keeping departments informed of new books published, and occasionally of questioning the purchase of particular items.

Through the cooperation of the coordinator, the library has the assurance that no new course will be offered until necessary materials, including library books, are available, or money for their purchase is in sight. The library, from its share of the funds, purchases not only reference books and continuations, but those books which "are likely to be of general interest to students, both academic and terminal."

\section{Defense Aid at Weber}

Eva R. Browning, librarian of Weber College, Ogden, Utah, described library cooperation particularly as it related to serving vocational and defense occupa- 
tional groups. While "instructors teach academic courses with their vocational values in mind" and "instructors in vocational courses consciously seek every opportunity to promote rounded cultural development," the institution recognizes the constant problem of avoiding a line of distinction between terminal and academic divisions.

The enrollees of the vocational school and the industrial trainees, a more mature and serious group, as well as other students, have been introduced to library tools, resources, and methods. A chain of leads, originating on the bulletin boards of the vocational school, has proved stimulating in bringing readers to the library for suggested books, periodicals, and miscellaneous pamphlet material on occupational and cultural subjects. Faculty members are informed of books and materials available, and funds are being sought to make possible the purchase of new printed matter to aid in occupational training and cultural development.

\section{Guidance at Bakersfield}

"A Study of the Individual Guidance of High School and Junior College Students" was prepared and sent to the conference by Goldie B. Ingles, librarian, Bakersfield Junior College. In her report she told of the evaluative study of guidance initiated at Bakersfield under the general direction of the Commission on Terminal Education of the American Association of Junior Colleges, and financed by a grant from the General Education Board. The problem of educational and vocational orientation of junior college terminal students is acknowledged to be particularly critical. The library cooperates by selecting and collecting career books, individual occupa- tional books, magazines such as Vocational Guidance, Vocational Trends, Occupations, and Occupational Index. The librarian gives individual assistance, too. "The orientation class, a first-year required course for academic students, studies vocations one semester, and the social problems class, a first-year required course for terminal students, studies vocations the next semester." This prevents overcrowding of the library and insures that each student is acquainted with the catalog, the Readers' Guide, and the occupational chart. As attention to guidance problems grows, the library hopes to continue its service to counselors and students.

\section{Los Angeles and San Francisco}

In a brief paper, Gladys Green introduced Los Angeles City College Library, emphasizing the efforts of the library staff to send out students bearing "pleasant associations with the printed page."

Marcus Skarstedt summarized the activities of San Francisco Junior College Library in a letter directed to the chairman. Most of the 13,000 volumes in the library have been "chosen with the definite aim in view of augmenting and supporting actual instruction in the various departments of the institution. The college at present offers a score or more of terminal or semi-professional curricula. Of course, the library seeks to make available to faculty and students the best available printed material in the field of each of these curricula. By 'best' we mean (I) up-to-date; (2) authoritative; (3) so written as to awaken a response in the mind of the average terminal student." The library further serves the instructional emphasis upon the use of periodical literature and pamphlet material. 


\section{Advisory Committees}

R. M. Lightfoot, Jr., librarian of Scranton-Keystone Junior College, presented a summary of achievements and plans for library cooperation particularly as they center around the work of community advisory committees. Present plans, though still incomplete, include four steps: ( I) a day by day file of every student's reading, a summary of which will be added to the student's personnel records; (2) a careful check on all literature of the occupation for which the college offers terminal courses; the purchase of as much as possible; and the issue of annotated bibliographies; (3) an especially strong effort to build up a knowledge of library procedures and develop the library habit in terminal students; (4) continuance of the custom of notifying faculty members of the appearance of new periodical material of particular interest to them.

\section{Library Service Curriculum}

The major paper of the afternoon session, "Should the Junior College Attempt a Terminal Curriculum in Library Service?" was prepared by Helen F. Pierce, librarian, Modesto Junior College.

Those who are responsible for curriculum planning and vocational guidance at the junior college level are looking about eagerly for new avenues into which they may direct their graduates. They advocate the introduction and development of semi-professional courses of a terminal nature in the fields where such curricula are feasible. This paper is devoted to evidence bearing on the question of whether the junior college should attempt a terminal semiprofessional curriculum in the library field.

This problem involves many others to which no satisfactory solution has as yet been found. Among these are the following:
What are to be the criteria applied to a vocational curriculum before its adoption? What is to be the philosophy of the junior college with respect to terminal education? What library positions are "semiprofessional" and what training produces the best personnel for such positions?

According to American Junior Colleges, forty-seven schools now offer semiprofessional library training. However inquiries sent to the librarians of these schools ${ }^{1}$ reveal the fact that all but eight deny giving a library course with any vocational intent or objective. Of these eight schools, two give noncredit courses. Two of the most ambitious programs outlined are offered by small private denominational junior colleges. Neither of these had any students enrolled in library courses at the time of the Eells survey, however.

The only large public junior college which reported having offered a terminal curriculum in library work was Los Angeles City College, one of the two schools where such courses have now been discontinued. The curriculum for clerical library aides was inaugurated there in September of 1937 after careful planning and adequate preparation. An elaborate selective procedure was set up to insure limiting enrollment to qualified students. A full-time teacher with a master's degree in library service as well as junior college library experience was added to the staff to conduct the courses. Ninety-eight girls were graduated from the curriculum in three years. Of these, nineteen are known at present to be employed as library clerks.

\section{Arguments against Vocational Library Courses}

The inadequacy of staff time and library resources in junior colleges are cited as two of the most urgent arguments against the introduction of vocational library courses. The median annual budget for junior college libraries reported in American Junior Colleges, exclusive of salaries, was $\$ 600$.

It is held that most workers must think in terms of fields of work rather than specific

1 Replies were received from 80 per cent of those addressed. 
jobs and that curricula should be planned to meet the demands of the former. On this account, and for the reasons that job placement possibilities seem slight in metropolitan areas where junior college libraries might be equipped to offer vocational library training, it is felt that the junior college should not attempt an entrance into this field.

The library section meeting on March I, considered the implications of national defense for our field. In the absence of Carl H. Milam, Kathryn P. Mier, assistant in the Public Libraries Division of the American Library Association, discussed "National Defense and Junior College Libraries." Miss Mier first read "The Library-I94I," a statement adopted by the A.L.A. Council at the December, I940, conference; then related the activities of the Association and libraries to it. Among the projects undertaken, she called attention to the survey of library resources conducted under the chairmanship of Robert B. Downs, director of libraries, New York University, mentioning printed reports now available and others planned. She noted, also a study of defense activities of college and university libraries, undertaken by the A.C.R.L. under the chairmanship of Charles Mohrhardt, chief, technology department, Detroit Public Library.

\section{Book Lists}

The second paper of the morning, on "Book Lists for Junior College Terminal Education Pertaining to National Defense," was prepared and read by Wave L. Noggle, librarian of the Junior College of Virginia, Minn. Recognizing that the librarian must consider the titles on any list in the light of, (I) present holdings; (2) new courses in the curriculum; (3) authoritativeness of the lists; and (4) purposes for which the lists were compiled, Mr. Noggle limited his discussion to a consideration of the last two points.

Four definitions of national defense were stated, and booklists representative of each type were discussed. The first definition, that of "patriotism" in its narrow sense, was one which librarians were advised to avoid. The so-called "poison" list of books, "Treason in the Textbooks," by $\mathrm{O}$. K. Armstrong was cited as a typical example of this variety. A second definition of national defense was "vocational education." The requirements of colleges cooperating with the government in the national defense program must be met in book lists in this group. Though some well-arranged lists are compiled and distributed by publishers, librarians were urged to give preference to those compiled by government agencies, educational, and library organizations. Aeronautic Training for National Defense, compiled by Paul Howard, was cited as an example of the excellent lists available.

The third definition was called "national security" as defined in the act of I9I6 which created the Council of $\mathrm{Na}$ tional Defense. No adequate buying list was cited. The last definition suggested was "total defense" which was held to include a study of long-term democracy and solidarity of our nation. The recent publications of the American Library Association were held to be excellent for this group and "superior to others for use in any phase of national defense."

Mary Vick Burney, librarian, University of Tennesseee Junior College, Martin ; Robert H. Wilkins, librarian, Woodrow Wilson Junior College, Chicago; and Thelma Vogt Taylor, librarian, Morgan Park Junior College, Chicago, directed the discussion. 